\title{
The Perils of Accommodation: Jesuit Missionary Strategies in the Early Modern World
}

\author{
Andrés I. Prieto \\ University of Colorado at Boulder \\ andres.prieto@colorado.edu
}

\begin{abstract}
The notion of accommodation, or the adaptation of one's message to one's audience, has been regarded as a central feature of the Jesuit way of proceeding at least since the seventeenth century. In recent years, scholars have come to understand accommodation as a rhetorical principle, which - while rooted in the rules of classical oratorypermeated all the works and ministries performed by the Jesuits of the Old Society. By comparing the theoretical notions about accommodation and the advantages and risks of adapting both the Christian message to native cultures and vice versa, this paper shows how and under what conditions the Jesuit missionaries were able to translate this rhetorical principle into a proselytizing praxis. By focusing on the examples of José de Acosta in Peru, Matteo Ricci in China, and of those Jesuits working in the missions in Paraguay and Chile, this essay will show how the needs in the missionary field superseded and overruled the theoretical requirements set beforehand. They revealed the ways in which the political and cultural context in which the missionaries operated determined the negotiations needed in order to achieve a common ground with their would-be converts if their mission was going to happen at all.
\end{abstract}

\section{Keywords}

accommodation - Jesuit missions - China - Chile - Paraguay - Peru - José Acosta (1540-1600) - Matteo Ricci (1551-1610)

In his Provincial Letters (1656), Pascal recounts how, among the "many strange things" he heard from a Jansenist friend regarding the Society of Jesus, there was a description of their accommodationist strategy. According to his friend,

(C) PRIETO, 2017 | DOI 10.1163/22141332-00403002

This is an open access article distributed under the terms of the Creative Commons Attribution-

Noncommercial 4.0 Unported (CC-BY-NC 4.0) License. http://creativecommons.org/licenses/by-nc/4,0/2623 06:56:50AM 
since the Jesuits' goal was to extend their influence everywhere and to govern all consciences, they readily adapted Christianity and its moral norms to every kind of person they might happen to encounter. The most appalling example was their behavior in China, a land where, since "the doctrine of a crucified God is accounted foolishness, they suppress the offence of the cross and preach only a glorious and not a suffering Jesus Christ," while allowing their converts to continue practicing their idolatrous rites. ${ }^{1}$ Eager to test the limits of Jesuit accommodation, Pascal decided to consult a Jesuit priest about the possibility of being excused from fasting. The Jesuit diligently released Pascal from the obligation, justifying his decision with quotes from Escobar, Suárez, and other Jesuit authorities in Probabilism. When Pascal inquired what would happen in the case other authorities, such as the Church Fathers, had expressed an opinion contrary to that of modern Jesuit moralists, the priest answered, "The Fathers were good enough for the morality of their own times; but they lived too far back for that of the present age." Moral rules and religious obligations, the Jesuit insisted, needed to be accommodated to present times and individual circumstances. ${ }^{2}$

Accommodation, the attitude that so outraged Pascal, had been a main feature of the Jesuit way of proceeding since the early years of the order; one that had been championed by Ignatius himself. Thus, for example, in the instructions he wrote in 1549 to Alfonso Salmerón (1515-85) and Peter Canisius (1521-97) with occasion of their mission to Ingolstadt, Ignatius recommended that in their actions and words they should "accommodate to the wits and affections" of those they had to deal with. ${ }^{3}$ Ignatius had given a similar directive to Paschase Broët (c.1500-62) and Salmerón in 1541, quoting 1 Cor 9:22 ("I have become all things to all people"). ${ }^{4}$ This scriptural justification notwithstanding, Jesuit accommodationism was rooted, ultimately, in the precepts of humanistic and classical rhetoric, as John O'Malley noted almost two decades ago. ${ }^{5}$ This "rhetorical principle" went beyond the needs of preaching, lecturing, and even of casuistry, and informed the theological and anthropological assumptions of Jesuit pastoral work. ${ }^{6}$ "The belief that God labors directly in the individual

1 Blaise Pascal, Pensées and The Provincial Letters, trans. W.F. Trotter and Thomas M'Crie (New York: Random House, 1941 [1656]), 375.

2 Pascal, Pensées and The Provincial Letters, 384.

3 Ignatius Loyola, Obras de San Ignacio de Loyola, ed. Ignacio Iparraguirre, Cándido de Dalmases, and Manuel Ruiz Jurado (Madrid: Biblioteca de Autores Cristianos, 1991), 866.

4 Loyola, Obras, $75^{2}$.

5 John W. O'Malley, “The Ministry to Outsiders: The Jesuits," in O’Malley, Saints or Devils Incarnate?: Studies in Jesuit History (Leiden: Brill, 2013), 89-97, here 90-91.

6 John W. O’Malley, The First Jesuits (Cambridge, MA: Harvard University Press, 1993), 255. 
and that the individual must then be accommodated was the fundamental premise of the [Spiritual] Exercises."7 This willingness to accommodate the individual and his or her circumstances was one of the main reasons for the Jesuit commitment to probabilistic thought in moral matters. ${ }^{8}$ Accommodation, although grounded in a definite conception of the relationship between God and the individual Christian, transcended the purely individual to inform the order's main ministries. ${ }^{9}$ Crucially (and most polemically, as Pascal's mordant satire makes clear) it also became associated with the evangelizing methods put in place by the Jesuits in their overseas missions.

The Jesuit willingness to accommodate themselves and their message to different audiences drew criticism from very early on. Almost a century before Pascal's Provincial Letters, Pero Fernandes Sardinha (1497-1556), bishop of Brazil, complained to the Jesuit superiors in Lisbon that their missionaries were going too far in embracing the native way of living, and accused them of being overly permissive with native rituals. ${ }^{10}$ Similar charges were often leveled against Jesuit missionaries, particularly by members of other religious orders. ${ }^{11}$ But not all criticisms came from the outside. Even though the rhetoric of accommodation permeated the spiritual and worldly activities of the Jesuits, not all members of the order agreed on how to translate this notion into actual practice. This was particularly so when accommodation moved away from the individual level to the adaptation of Christianity to non-European cultures, that is to say, when accommodation happened in the contexts that so distressed critics such as Pascal or Fernandes Sardinha. In the following pages, I will trace the development of different Jesuit ideas and practices regarding accommodation in places as diverse as Ming China and seventeenth-century Chile and Paraguay. My goal is to underscore the wide range of attitudes early modern Jesuits had regarding accommodation, from

Stephen Schloesser, "Accommodation as a Rhetorical Principle: Twenty Years after John O'Malley's The First Jesuits (1993)," Journal of Jesuit Studies 1, no. 3 (2014): 347-72, here 356.

Robert A. Maryks, Saint Cicero and the Jesuits: The Influence of the Liberal Arts on the Adoption of Moral Probabilism (Aldershot: Ashgate, 2008), 79-80.

9 O'Malley, First Jesuits, 256; Schloesser, "Accommodation as a Rhetorical Principle," 348-64. 10 Judith Shapiro, "From Tupã to the Land Without Evil: The Christianization of TupiGuarani Cosmology," American Ethnologist 14, no. 1 (1987): 126-39, here 129.

11 For a summary of the different criticisms faced by Jesuit missionaries regarding the practice of accommodation in the early modern period, see Jonathan Wright, God's Soldiers: Adventure, Politics, Intrigue, and Power; A History of the Jesuits (New York: Doubleday, 2004), 116-23. 
seeing it as a necessary step towards the conversion of native peoples to its total rejection in missionary settings. I will begin by discussing the practices put forth by Alessandro Valignano (1539-1606) and implemented by Matteo Ricci $\left(155^{2-1610}\right)$ when trying to found a Chinese Christianity. Their decisions regarding how to best adapt Christianity to the social and cultural milieu of late Ming China are among the first examples of accommodation in the overseas missions, and one of the most polemic. Ricci's strategic decisions still inform our discussions of Jesuit evangelizing practices among non-European peoples. I will then examine the writings of one of the most influential Jesuit missiologists of the sixteenth century, José de Acosta (1540-16oo). Acosta's dislike of accommodationist strategies had a profound influence in the development of pastoral texts and attitudes in the South American church well into the seventeenth century. Yet, for all his influence, his opinions were not always heeded by those Jesuits that came after him, who felt the need to compromise and search for a common ground with their audiences in the missionary field. I will finish this essay by analyzing the ways in which Luis de Valdivia (1561-1642) adapted Acosta's texts to the realities and needs of pastoral work in seventeenth-century Chile, while still managing to accommodate their message to his audience reactions.

In the last two decades, accommodation, understood both as a rhetorical principle and a missionary practice, has come to be accepted by most scholars as a staple of the Jesuit way of proceeding. Yet, as I hope to show in the following pages, early modern Jesuits did not agree on the exact meaning of accommodation. This is particularly true in the thorny issue of what aspects of Christianity, and to which degree, it was convenient to present to native cultures outside the Mediterranean. As we will see, Jesuit attitudes regarding accommodation ran the gamut from cherry-picking some aspects of Christianity while hiding or downplaying others, to a purely rhetorical and extremely rigorist interpretation of the principle. By studying the theoretical and practical challenges faced by Jesuit missionaries, my goal will be to highlight the variety of attitudes towards accommodation within Jesuit ranks, that is to say, to unravel some of the different manners in which the Jesuits themselves view one of the key elements of their way of proceeding.

\section{Valignano, Ricci, and Accommodation in China}

Perhaps the best-known example of Jesuit accommodationist strategies is that of the China mission and the so-called rites controversy. Alessandro Valignano, visitor of Asia, developed in the late 1570 s and early 1580 s a policy of 
accommodation for the Jesuits working in China and in Japan..$^{12}$ Even though Valignano would eventually become disappointed with the reception of Christianity by the Japanese ${ }^{13}$ he nonetheless insisted that the missionaries learned Mandarin and Japanese, and that they adopted the clothes and customs of the Chinese. ${ }^{14}$ Valignano was, of course, following the guidelines laid out in the order's Constitutions, according to which the Jesuits' garb had to conform to local use. ${ }^{15}$ Yet, Valignano took the idea of accommodation a step further by making the crucial assumption that, with more "civilized" peoples such as the Chinese and the Japanese, one could tolerate diversity of customs and find a common moral ground on the basis of natural law to facilitate their conversion. ${ }^{16}$ Following Valignano's suggestions and his own observations, the first Jesuit missionary in China, Michele Ruggieri (1543-1607), adopted the persona of a Buddhist monk. Ruggieri, who had been laboriously studying Chinese in Macao in preparation for his mission, published a catechism titled, Tianzhu Shilu (1584), the first catechism in Chinese characters ever to be used in mainland China. In it, he presented himself as Tianchu seng, a monk from India, the land of Buddha. This choice was in part motivated by Ruggieri's desire to portray himself and his companion, Matteo Ricci, as Westerners without fully identifying themselves with the more aggressive Portuguese merchants from Macao. But it also reflects the fact that, in the religious climate of late Ming China, the Jesuits and the religion they preached (their claims to uniqueness notwithstanding) were initially perceived by the Chinese Mandarins of Zhaoqing through the lens of Buddhism. ${ }^{17}$

12 Edward J. Malatesta, "Alessandro Valignano Fan Li-An (1539-1609): Strategist of the Jesuit Mission in China," in Portrait of a Jesuit: Alessandro Valignano (Macau: Macau Ricci Institute, 2013), 121-43, here 134; Catherine Pagani, "Clockwork and the Jesuit Mission in China," in The Jesuits II: Cultures, Sciences, and the Arts, 1540-1773, ed. John W. O'Malley et al. (Toronto: Toronto University Press, 2006), 658-77, here 659 .

13 Jonathan D. Spence, The Memory Palace of Matteo Ricci (New York: Penguin, 1985), 42.

14 Nicolas Standaert, "Jesuits in China," in The Cambridge Companion to the Jesuits, ed. Thomas Worcester (Cambridge, Cambridge University Press, 2008), 169-85, here 172; Mary Laven, Mission to China: Matteo Ricci and the Jesuit Encounter with the East (London: Faber \& Faber, 2011), 45-46.

15 Ignatius Loyola, The Constitutions of the Society of Jesus, trans. George E. Ganss (St. Louis, мо: Institute of Jesuit Sources, 1970), 357-79.

16 Joan-Pau Rubiés, "The Concept of Cultural Dialogue and the Jesuit Method of Accommodation: Between Idolatry and Civilization," Archivum historicum Societatis Iesu 74, no. 147 (2005): 237-80, here 249 .

17 Ronnie Po-Chia Hsia, A Jesuit in the Forbidden City: Matteo Ricci, 1552-1610 (Oxford: Oxford University Press, 2010), 90-93. 
Ruggieri was sent back to Rome in November 1588. Although his missionto secure a papal embassy to the Ming Emperor in order to strengthen the Jesuit position in the Middle Kingdom - never came to fruition, his departure represented a turning point for the Jesuit accommodationist strategy in China. Between 1589 and 1593, Ricci refashioned his own identity and the missionary program of the China mission. This new program was based on a complete rejection of Buddhism, a change in orientation that Valignano approved in $1593 .{ }^{18}$ Not introducing himself anymore as a monk from India, Ricci let his hair and beard grow and began studying the Confucian classics, gradually assuming the identity of a Confucian scholar. His first book in Chinese script, Jiaoyun Lun (1595) was a collection of maxims and anecdotes culled from Stoic and Patristic sources dealing with male friendship, one of the five basic human relationships in Confucian doctrine. Significantly, Ricci presented himself in the proem of the book as having come "from the Far West," and not from India anymore. ${ }^{19}$ Furthermore, he stopped calling himself a monk, and used instead the term shenren, a term usually employed to describe Ming literati who did not hold office or who had retired from lower posts in order to be employed by other Mandarins in their literary projects. ${ }^{20}$ His following book, Xiguo Jifa (1596), intended as a present for the governor of Jiangxi, Lu Wangai, also addressed another central focus of concern for the Mandarins: the art of memory. It was, in fact, meant to instruct the governor's sons in the techniques of European mnemonics to help them pass the grueling qualifying exams that determined the careers of all Mandarins in the empire. ${ }^{21}$

Ricci's rejection of Buddhism and his subsequent adoption of the habits, clothing, and demeanor of Confucian literati, were a tactical move. Aware of the lower social status of Buddhist monks in late Ming society, and the centrality of the Confucian rituals and literary cannon in the public lives of his office-holding patrons, Ricci refashioned himself as a scholar as soon as Ruggieri (who was comfortable in his persona as a Tianchu seng) departed for Rome. Famously, Ricci would develop a view of Confucianism not as a religion, but as a civil practice; a political philosophy that was atheistic at its core and, therefore, compatible with Christianity if one could get past the more recent Buddhist and Daoist metaphysical additions to it. ${ }^{22}$ Even though the

18 Malatesta, "Alessandro Valignano," 126.

19 Matteo Ricci, On Friendship: One Hundred Maxims for a Chinese Prince, trans. Timothy Billings (New York: Columbia University Press, 2009 [1595]), 87.

20 Hsia, Jesuit in the Forbidden City, 156.

21 Spence, The Memory Palace, 3-4.

22 Liam M. Brockey, Journey to the East: The Jesuit Mission to China, 1579-1724 (Cambridge, MA: Harvard University Press, 2007), 106-7; Spence, The Memory Palace, 210. 
Mandarins attended the temples, performed rites, and burned incense during Confucian holidays, Ricci saw these practices as grounded in a moral philosophy whose emphasis on state and family made it akin to classic Stoicism, and not a form of idolatry. ${ }^{23}$ Confucianism, Ricci claimed, was not a religious law (legge), but an "academia," instituted for the good governance of the republic. It could, then, be Christianized, since "nel suo essentiale non contiene niente contra l'essentia della fede Catholica [in its essence it does not contain anything against the essence of the Catholic faith]."24

However, Ricci's synthesis of Christian and Confucian doctrines was more than a tactical maneuver. In the complex religious climate of late Ming China, several schools of thought offered competing syntheses between the three major religions, Buddhism, Daoism, and Confucianism. To complicate matters more, at the time Ricci and Ruggieri began their missionary sojourn into the Middle Kingdom, at least some scholars and officials were seeking to reform the Mandarin class, paralyzed, in their opinion, by the influence of Buddhism. ${ }^{25}$ One of these scholars was Zhang Huang (1527-1608), who presided over the White Deer Grotto Academy in Nangchang, where Ricci resided from 1595 to 1598. Zhang Huang understood Confucianism as the practice of moral virtue, and his reading of the doctrines of Confucius and Mencius was predicated on a metaphysics derived from his studies of the I-Ching. ${ }^{26}$ Ricci stroke a friendship with the Confucian sage, and attended the monthly gatherings at the Academy he presided. There, aside from being exposed to more in-depth discussions of the Confucian doctrines and canonical texts, Ricci also expounded about Christianity. It was from these discussions that a number of points of convergence between the two men's intellectual programs became evident: A stress on self-discipline and introspection; a return to the text of the Confucian classics in order to reconstruct a Confucian orthodoxy free of Buddhist and Daoist accretions; the practice of moral knowledge in daily life; and the search for harmony between the study of nature and self-cultivation, all important topics in Ricci's Tianzhu Shiyi, the catechism he published in $1603 .{ }^{27}$ On top of

\footnotetext{
23 Ana Carolina Hosne, The Jesuit Missions to China and Peru, 1570-1610: Expectations and Appraisals of Expansionism (New York: Routledge, 2013), 86.

24 Matteo Ricci, Descrizione della Cina, ed. Bernardo Valli (Macerata: Quodlibet, 2011 [1610]), 144.

25 Yu Sanle, "Seeking the Truth from the West: A Generation of Giants in Late Ming China," in Culture, Art, Religion: Wu Li (1632-1718) and His Inner Journey (Macau: Macau Ricci Institute, 2006), 459-84, here 462-63.

26 Hsia, Jesuit in the Forbidden City, 160.

27 Ibid., 159-6o.
} 
the intellectual influence Zhang Huang had on Ricci's understanding of Confucianism, some high-placed officers, such as Xu Guanqi (1562-1633), custodian of the Heir Apparent and grand secretary of the Hall of Literary Profundity, saw Catholicism and Western knowledge as instrumental to free Confucianism from Buddhist influences, therefore offering Ricci their protection, embracing Christianity, and helping disseminate Western doctrines and ideas. ${ }^{28}$ In the end, and more important than the particular attacks on certain forms of Chinese Buddhism, such as Chan meditation, that scholars like Zhang Huang waged, it was the general climate amiable to religious synthesis that favored Ricci's accommodationist strategy. As Mungello has pointedly remarked, the best sign of Ricci's sinification lays not in what he rejected, but in his attempt to synthesize Confucian and Christian doctrines. ${ }^{29}$

After Ricci's passing in 1610, the Jesuit accommodationist strategy in China came under attack, particularly by newly arrived Franciscan and Dominican missionaries. The newcomers came imbued with a more rigorist Counter-Reformation approach to the teaching of dogma, and saw Confucian rites not as civil practices, but as an idolatrous cult of ancestors. Reports of the Jesuit permissiveness reached Rome, and the controversy over Confucian rites and their place (or lack thereof) in Chinese Catholicism escalated. Finally, in 1704, the pope decided to condemn Ricci's compromises, which in turn led Kangxi, the Qing Emperor, to withdraw his protection of the Jesuits. ${ }^{30}$

\section{José de Acosta and the Jesuit Opposition to Accommodation}

Even though Ricci—and the China mission more generally—has become the emblem of the Jesuit missionary strategy, not all sixteenth-century Jesuits shared Ricci's and Valignano's positive view of accommodation. In fact, some

28 Yu Sanle has argued that both Jesuit missionaries and Chinese mandarins were responsible for the introduction of Christianity into China (Sanle, "Seeking the Truth from the West," 459-84). On Xu Guanqi and his efforts to disseminate Western ideas, see Roger Hart, Imagined Civilizations: China, the West, and Their First Encounter (Baltimore: The John Hopkins University Press, 2013), 195-256.

29 David E. Mungello, Curious Land: Jesuit Accommodation and the Origins of Sinology (Honolulu: University of Hawaii Press, 1989), 62.

30 The full history of the Rites Controversy falls outside my scope here. For a brief summary, see Brockey,Journey to the East, 104-7; Mungello, Curious Land; and George Minamiki, The Chinese Rites Controversy from Its Beginning to Modern Times (Chicago: Loyola University Press, 1985), 25-76. For the Dominican perspective, see James S. Cummins, A Question of Rites: Friar Domingo de Navarrete and the Jesuits in China (Aldershot: Scolar Press, 1993). 
of the leading missiologists of the order, such as José de Acosta, alarmed by what they perceived as a dangerous practice, sought to curb the use of crosscultural adaptations in missionary settings. In recent years, there has been a tendency among historians to compare Ricci to Acosta, precisely on the issue of their attitudes toward native cultures. Thus, for instance, Joan-Pau Rubiés has commented that Acosta's view of native cultures was more rigorist than Ricci's, seeing native rituals as thoroughly inspired by the devil. ${ }^{31}$ More recently, Ana Carolina Hosne has compared Ricci's accommodationist strategy to Acosta's idea of Hispanicization or acculturation, famously exemplified by his remark in De procuranda that the Andean natives needed to be taught how to be human before they could be taught how to be Christians. ${ }^{32}$ Predictably, the comparison (motivated by the fact that they were roughly contemporaries and by their inescapable influence in China and Peru, respectively) is only partially satisfactory. As Hosne has documented, Acosta's position towards Andean culture was deeply ambiguous, and nothing similar to Ricci's saving view of Confucianism can be found in his writings.

One could argue that the comparison between Ricci and Acosta yields only partially satisfactory results due to the different nature of their engagement with native cultures. Ricci spent almost three decades founding and spiritually tending to Christian communities first in the Guangdong province and later in the imperial capitals of Nanjing and Beijing. In the process, he transformed himself to look, sound, and behave like a Mandarin, to the point that, at a banquet in Nanchang, a Mandarin gave Ricci the supreme compliment of publicly saying that there was nothing foreign about the Italian Jesuit, except for his face. ${ }^{33}$ Acosta, on the other hand, never spent any meaningful amount of time among native communities and he never learned Quechua or Aymara, the two main indigenous languages in the Andes. Except for a few sermons preached during short visits to native parishes, he never got personally involved in the nitty-gritty of missionary work. The difference between Acosta the administrator and Ricci the missionary had a profound effect on their views on accommodation. It is important to keep in mind that, as the examples of both Jesuits show, there were at least two different ways of going about accommodation. The first one was the adaptation of Christian dogma to different cultural realities, without betraying the essence of the faith. This is what modern theologians call inculturation, and is visible in the emphasis Acosta put on simplifying both the language and the reasoning used to preach the fundamental

\footnotetext{
31 Rubiés, "The Concept of Cultural Dialogue," 246.

32 Hosne, Jesuit Missions to China and Peru, 76.

33 Hsia, Jesuit in the Forbidden City, 167.
} 
Christian precepts to the Andean natives. The preacher "must accommodate himself completely to his audience," Acosta remarked in 1584, although that did not mean picking and choosing what aspects of the faith they were taught or how to interpret them. ${ }^{34}$ On the other hand, accommodation can refer to the adaptation of non-Christian customs or beliefs to Christian ends, or the reinterpretation of non-Christian traditions in order to make them more amenable to Christian indoctrination. In this sense, accommodation represents more than just a rhetorical compromise, as in the case of inculturation, but rather a conceptual compromise designed to bridge the chasm between the missionary's and the would-be convert's cultures. This was Valignanos's and, especially, Ricci's understanding (although Ricci did practice some measure of inculturation in his pastoral writings, particularly in his Tianzhu Shiyi).

Acosta's position on accommodation became more and more conservative over time. In his handbook for missionaries, De procuranda Indorum salute, which he wrote in 1576 , Acosta refuted in strong terms those who advocated teaching only certain aspects of the faith to the natives, based on their perceived intellectual capabilities. Acosta complained that some modern theologians maintained that the Indians could be saved without an explicit knowledge of Christ or his sacrifice, an opinion he considered an absurdity. ${ }^{35} \mathrm{He}$ was well aware that these theologians had developed this theory out of a concern for the natives, who for so many centuries had been deprived of the revelation, and therefore, of any knowledge of Christ. Yet, he insisted, "this doctrine [...] is so openly heretic that there is nothing that could be more at odds with the faith than to say that anyone can be saved without [explicit faith in Christ]." ${ }^{36}$ The minimum every neophyte was expected to know was spelled out in the long and short catechisms he prepared for the Third Lima Council (1582-83) and in the Tercero cathecismo, a collection of sermons Acosta published under the council's imprint. In the prologue to the Tercero cathecismo, Acosta insisted in what the catechumens needed to know before baptism:

34 José de Acosta, Tercero cathecismo y exposicion de la doctrina christiana por sermones (Lima: Antonio Ricardo, 1585), 4.

35 José de Acosta, De procuranda Indorum salute (Madrid: C.S.I.C, 1984 [1589]), 2:188-89.

36 Ibid., 2:191. Incidentally, it was precisely notions such as the original sin, the passion of Christ, his resurrection and its larger meaning in the economy of salvation that Ricci left out of his Tianzhu Shiyi, which presented to the Chinese readers what Ronnie Po-Chia Hsia has called "a pared-down Christianity" (Hsia, Jesuit in the Forbidden City, 224). It was this aspect of Ricci's strategy that drew the ire of critics such as Pascal, as we have already seen. 
And so it is convenient that, as with dull disciples, we try to instill in them the most essential points of our faith, especially those which they ignore the most, such as the unity of one God, and that we must not worship more than one God, that Jesus Christ is God and man, and the only savior of men, that through sin man loses Heaven and is damned forever, that to free oneself from sin, one has to get baptized, or to confess all sins; that God is Father, Son, and Holy Ghost, that there is another life and eternal damnation for the wicked and eternal glory for the just. ${ }^{37}$

All this was explained in the catechisms, which were organized as a series of questions and answers meant to be memorized by the native neophytes, covering every article of faith from the Nicene Creed.

Unlike previous evangelizing efforts, after the Third Lima Council (in which Acosta had a decisive intervention), the South American church moved away from trying to accommodate both language and content to its native audiences and towards a more uniform program of religious indoctrination..$^{38}$ Acosta rejected earlier accommodationist missionary practices, like the use of native words or neologisms to translate key doctrinal concepts, such as God, church, holy cross, and others into native languages. ${ }^{39}$ This was reflected in the lexical choices of the trilingual texts published under the imprint of the Third Lima Council: in the Quechua and Aymara versions, these terms were simply expressed with loan words from Spanish in order to achieve both unity in the instruction given across the Andes and to minimize the possibilities of misinterpretation by the natives. Otherwise, the missionaries risked "a lot of confusion [among their converts], and even occasions for these Indians to think that they are being taught different doctrines through different terms."40

One can trace the evolution of Acosta's anti-accommodationist ideas from the mid-1570s to 1590 , the date of his last published work. In 1576, when he was beginning to formulate his ideas on the proper amount of dogma native neophytes should know before baptism, and the convenience of using Spanish instead of native terms for certain doctrinal concepts, Acosta could still accept

37 Acosta, Tercero cathecismo, $3^{\mathrm{v}}-4^{\mathrm{r}}$.

38 Juan Carlos Estenssoro Fuchs, Del paganismo a la santidad: La incorporación de los indios del Perú al catolicismo, 1532-175o, trans. Gabriela Ramos (Lima: IfEA, 2003), 188-89; Alan Durston, Pastoral Quechua: The History of Christian Translation in Colonial Peru, 1550-1650 (Notre Dame, IN: University of Notre Dame Press, 2007), 84-85.

Acosta, De procuranda Indorum salute, 2:75.

40 José de Acosta, Doctrina Christiana y catecismo para instruccion de los indios (Lima: Antonio Ricardo, 1584). 
the use of Christianized Andean songs and dances in missionary contexts. On December 21, 1576, Acosta visited the Jesuit mission in Juli, on the shores of Lake Titicaca. He was pleased to see that he was welcomed by "a most solemn reception" that included native dancers of all ages, even "children who could barely walk," singing and dancing Christianized versions of takies, traditional Andean songs. ${ }^{41}$ By the end of the decade of 1580 , however, Acosta was denouncing all native ritual practices as demonic inversions of Christian sacraments and rituals, and therefore irredeemable for Christian use. ${ }^{42}$ By 1590, his concept of accommodation had ceased having anything to do with the adaptation of Christianity to non-Christian cultures. In his treatise, De Christo revelato (1590), Acosta defined accommodation not as a way to adapt Christianity to new cultural realities but as a method of interpreting scripture by extending its meanings to topics and events the biblical authors could not have predicted. ${ }^{43}$ But even in this heavily restricted sense, Acosta still insisted that accommodation had no place in missionary settings. Missionaries should stick to teaching neophytes only the literal and historical sense of the sacred text and nothing more. ${ }^{44}$

\section{Missionary Strategies in South America}

As several scholars have noted, Acosta's emphasis on inculturation over accommodation was expressed in his rejection of the use of Quechua words and Quechua neologisms to translate key doctrinal concepts, a position made church policy by the Third Lima Council. ${ }^{45}$ However, one must be careful in assigning too much weight to this indictment. Other Jesuits in South America had a more liberal view of accommodation. Tellingly, they usually had a more prolonged exposure to native cultures and to the realities and needs in the missionary field. Thus, when in 1639 Antonio Ruiz de Montoya (1585-1652) published his dictionary and grammar of the Guarani language, he decided to follow a route more akin to Ricci's than to Acosta's. In his Arte y bocabulario,

41 Antonio Egaña, ed., Monumenta Peruana, 7 vols. (Rome: Monumenta Historica Societatis Iesu, 1954-81), 2:279.

42 José de Acosta, Historia natural y moral de las Indias, ed. José Alcina Franch (Madrid: Dastin, 2002 [1590]), 358-59.

43 Sabine MacCormack, Religion in the Andes: Vision and Imagination in Early Colonial Peru (Princeton, NJ: Princeton University Press, 1991), 262.

44 José de Acosta, De Christo revelato libri novem (Rome: Jacob Tornerius, 1590), 99.

45 Durston, Pastoral Quechua, 84-85. 
Ruiz de Montoya translated "soul” with the Guarani notion of ang, and used the name of a Tupi-Guarani deity, Tupâ, to refer to the Christian God. ${ }^{46}$ The use of native words to name Christian concepts became the standard Jesuit practice in Paraguay, but it also opened up a flank to the attacks of the enemies of the order. Barely a decade after the publication of Ruiz de Montoya's Arte y bocabulario, the Franciscan bishop of Asunción, Friar Bernardino de Cárdenas (1579-1668), violently engaged the Jesuits, to the point of an armed confrontation that resulted in the burning down of the Jesuit college of Asunción and a retaliatory expedition against the bishop's supporters by a squadron of reduction Guarani armed with fire weapons. ${ }^{47}$ According to the Jesuit provincial, Joan Baptista Ferrufino (1581-1655), the conflict originated in the Jesuit negative to recognize Cárdenas as the legitimate bishop of Paraguay. Cárdenas had obtained local support by promising to expel the Jesuits and to redistribute the natives from the reductions among the Spanish settlers, who could thus put them to work in their fields. ${ }^{48}$ Among the many reasons Cárdenas gave for his attempts to banish the Jesuits from his see were, significantly, their accommodating practices. Cárdenas, in particular, objected to the use of Tupâ, "which they use in their catechism instead of the sovereign name of God, which they reject so they can use the name Tupá, which is abominable, being the proper name of some demon, as it is that of Tubá, which they use instead of that of God Our Father." 49 Ultimately, the conflict between the bishop and the Jesuits was resolved favorably for the latter when Cárdenas left Asunción in 1651, freeing the Jesuits to continue their accommodating strategies. In 1724, the Jesuit Paulo Restivo (1658-1740) asked the Guarani chief Nicolás Yapuguay (1680-?) to translate a commented catechism into the Guarani language. The printing press the Jesuits had in the mission of Santa María la Mayor published the resulting book. Even though loan words from Spanish appear throughout the text, they refer mainly to secular cultural concepts introduced by the missionaries (although some loan words are used for Christian concepts, such as

46 Antonio Ruiz de Montoya, Arte y bocabulario de la lengua guaraní (Madrid:Juan Sánchez, 1640), 153 and 323 .

47 Barbara Ganson, The Guaraní under Spanish Rule in the Río de la Plata (Stanford, CA: Stanford University Press, 2003), 48-49.

48 Joan Baptista Ferrufino, "Letter to the Jesuit Procurator in Madrid, Buenos Aires, January 30, 1648," Archivo Nacional de Chile, Santiago, Fondo Jesuitas 196.7-8 (1648), 7 .

49 Bernandino de Cárdenas et al., Colección general de documentos tocantes a la persecución que los regulares de la Compañía suscitaron y siguieron tenazmente por medio de sus jueces conservadores y ganando algunos ministros seculares desde 1644 a 1660 contra el Ilustrísimo y Reverendísimo Sr. Don Fr. Bernardino de Cárdenas, (Madrid: Imprenta Real de la Gaceta, 1768), 2:92-93. 
"sacramento" or "Santa Madre Iglesia"). Yapuguay consistently used Tupâ to refer to the Christian God. Thus, for instance, the sentence "the Ten Commandments of God" became "Tupâ ñandequaitaba diez" in Yapuguay's translation. ${ }^{50}$

The use of native helpers to translate pastoral texts had a long tradition among the Jesuits in South America. Ferrufino himself, working in the Chiloe archipelago in southern Chile in 1609 (before becoming provincial of Paraguay), enlisted the help of two un-Christianized natives to translate a catechism. The southern part of the archipelago was inhabited by the Chono people, who spoke a different language than the Mapuche peoples of continental Chile, who had been up to that point the focus of Jesuit proselytizing efforts in the area. The Jesuits had already translated Acosta's 1584 catechism into Mapudungun, the Mapuche language. Since Chono groups regularly travelled to the Spanish settlements on the main island to barter, Ferrufino used this opportunity to enlist the help of two Chono traders who also spoke Mapudungun to translate the catechism into their language. Upon completing the task, Ferrufino checked the quality of the resulting translation with several people "who told me it was good." Although the resulting catechism is lost, we can surmise that the double translation (from Spanish into Mapudungun and from there into the Chono language) and, above all, the use of non-Christian native translators would have been condemned by Acosta as inappropriate and outright dangerous.

The translator of Acosta's catechism and confession manual into the Mapudungun language was Luis de Valdivia, one of the most important Jesuits in seventeenth-century Chile. Born in 1561 in Granada, Spain, Valdivia joined the Society of Jesus in 1580 . Soon after being ordained, Valdivia was sent to Peru, where he showed to be a good linguist and a good administrator. ${ }^{52}$ In 1593, he was part of the first group of Jesuits sent to establish a mission in Chile. There, he occupied the rectorate of the College of San Miguel in Santiago, and

$50 \quad$ Nicolás Yapuguay and Paulo Restivo, Explicacion de el catechismo en lengua guarani (Santa María la Mayor, Paraguay: n. p., 1724), 3.

$5^{1} \quad$ Emilio Ravignani and Carlos Leonhardt, Documentos para la historia argentina, vol. 19 (Buenos Aires: Facultad de Filosofía y Letras-Instituto de Investigaciones Históricas, 1927), 111.

$5^{2}$ Aside from learning Quechua and later translating the catechism and Acosta's sermons into Mapudungun, Valdivia also wrote grammars and short dictionaries of the Millcayac and Allentillac languages, which were spoken near Cuyo, Argentina; see Alexander Chamberlain, "The Allentiacan, Bororoan, and Calchaquian Linguistic Stocks of South America," American Anthropologist 14, no. 3 (1912): 499-507; and Horacio Zapater, La búsqueda de la paz en la guerra de Arauco: Padre Luis de Valdivia (Santiago: Editorial Andrés Bello, 1992), 69-71. 
was charged with preaching to the native population of the city. ${ }^{53}$ Although Valdivia has been saluted by Chilean historians as a promoter of native rights, the fact is that in the late 159 os we found him cozying up to the military elite rather than working with the natives. After the 1598 uprising, when Mapuche forces killed Governor Martín García Óñez de Loyola (b. 1548; nephew of Ignatius) and destroyed all Spanish settlements south of the Bío Bío River, Valdivia publicly endorsed the enslaving of all rebel natives. ${ }^{54}$ Valdivia's closeness to the political and military powers worried his superior, Provincial Rodrigo de Cabredo (1560-1618), who in 1602 ordered him back to Lima. This was the tipping point of his career. As Díaz Blanco has recently documented, it was in Lima that Valdivia came into contact with the Lascasista faction of the Peruvian Jesuits and had a change of heart regarding the Mapuche. ${ }^{55}$ From 1605 on, Valdivia's writings articulated his newfound views on the evils of personal service and the rights of the natives, views that would underwrite his defensive war strategy. In a nutshell, the strategy implied halting all military operations against the Mapuche; establishing a border between Spanish and Mapuche lands, punctuated by the strings of forts built by Governor Alonso de Ribera in 1602; and sending missionaries into rebel territory to preach Christianity and obtain the voluntary submission of the lonkos (Mapuche leaders) to the Spanish crown. After a trip to Spain to lobby for the change of military tactics, Valdivia came back to Chile in 1612, endowed with ample powers to oversee the implementation of the defensive war strategy. He began touring the Mapuche lands, notifying the lonkos of the policy change and, for the first time in his career, doing actual missionary work.

Once back in Spain in 1621, Valdivia published a translation into Mapudungun of the first nine homilies from Acosta's Tercero cathecismo. By and large, scholars have parsed these sermons for what they reveal about Valdivia's grasp of Mapuche culture, or to probe into Valdivia's translational practices and

53 For Valdivia's biography, see Horacio Zapater, La búsqueda, 19-37 and Eduardo Tampe, Catálogo de jesuitas de Chile (1593-1767): Catálogo de regulares de la Compañía en el antiguo Reino de Chile y en el destierro (Santiago: Ediciones Universidad Alberto Hurtado-Instituto de Historia Pontifícia Universidad Católica de Chile-Centro de Investigaciones Barros Arana-DIBAM, 2008), 257. More recently, José M. Díaz Blanco has shed new light on Valdivia's political activities in the 1590 and the early 16oos: José M. Díaz Blanco, El alma en la palabra: Escritos inéditos del padre Luis de Valdivia (Santiago: Ediciones Universidad Alberto Hurtado-Instituto de Historia Pontifícia Universidad Católica de Chile, 2011), 30-36.

54 Melchor Calderón, Tratado de la importancia y utilidad que ay en dar por esclavos a los indios rebelados de Chile (Madrid, 1601), 24; Enrique García Ahumada, "La inculturación en la catequesis inicial de América," Anuario de historia de la Iglesia 3 (1994):215-32, here 229.

Díaz Blanco, El alma en la palabra, 31-33. 
methods. ${ }^{56}$ Yet, Valdivia did not simply translate Acosta's Spanish original into a new language. Even though for the most part he followed Acosta's exposition, Valdivia decided to paraphrase and in some cases outright change the original Spanish text instead of simply translating it into Mapudungun. A good example of Valdivia's adaptation of Acosta's text is the sixth sermon, which introduces to the audience the concept of good and bad angels, and their role within the economy of salvation. Valdivia followed Acosta closely, save for emphasizing a certain aspect or explaining a concept in more detail. But, in a spectacular departure from his model, Valdivia introduced in this sermon the story of Lucifer's rebellion and subsequent fall from grace, completely absent in Acosta's original. Lucifer was "the most beautiful, the wisest, the strongest, most powerful and more excellent in everything than any other angels." Yet, Lucifer dared compare himself to God, claiming to be on equal footing with him. "Who is there like me? Who is my equal," he asked, "Nobody, I exceed every one." Lucifer convinced other angels to follow him against God. But Lucifer's rebellion was crushed, and God banished him and all his followers from Heaven, throwing them down to Earth, to a life of torments and suffering. Lucifer's sin was pride, the sin most abhorrent to God, according to Valdivia. "For this reason, everything he had received from God (which was a lot), he did not thank, just as if he had not received it." ${ }^{57}$

The inclusion of stories such as this goes beyond inculturation and falls squarely into the more restrictive view of accommodation that Acosta had banned from the missions: the allegorical reading of sacred history to apply it to a new reality unforeseen by the sacred writers, in this case, the colonial situation of the lonkos. In all likelihood, the Mapuche understood Lucifer's rebellion and his punishment as more or less transparent allusions to the 1598 rebellion and the massive enslavement that came upon them as a consequence. In this way, this story not only helped Valdivia present a more coherent explanation

$5^{6}$ Ana Carina Kosel, "Los sermones de Valdivia: Distribución de lugares, didáctica y polémica en un testimonio del choque de dos culturas," Anuario de estudios americanos 55, no. 1 (1997): 229-44; María T. Aedo Fuentes, "El doble discurso de la frontera: Los textos catequísticos del padre Luis de Valdivia," Acta literaria 30 (2005): 97-110; José Quidel Lincoleo, "Rol y presencia del Mapuzungun en la colonia frente al proceso de evangelización," in Ta Iñ Fijke Xipa Rakizuameluwün: Historia, colonialismo y resistencia desde el país Mapuche, ed. Comunidad de Historia Mapuche (Temuco: Ediciones Comunidad de Historia Mapuche, 2012), 45-63; Gertrudis Payas, José M. Zavala, and Mario Samaniego, "Al filo del malentendido y la incomprensión: El padre Luis de Valdivia y la mediación lingüística," Historia 45, no. 1 (2012): 69-9o.

57 Luis de Valdivia, Sermon en lengua de Chile de los mysterios de nuestra Santa Fe Catholica (Valladolid: n.p., 1621), 41-43. 
for the existence of evil; it also helped him subtly tie in proper Christian behavior to political subservience, that is to say, it allowed him to simultaneously advance the political and the religious ends of his defensive war strategy.

But perhaps the best example of Valdivia's accommodationism comes not from the sermons he published, but from his missionary work among the Mapuche people. Although most interactions between missionaries and native peoples are lost to the historian, sometimes a stroke of luck allows us a glimpse into the complex cultural negotiations involved. In his Historia de la Compañía de Jesús de la provincia del Paraguay (1755), Pedro Lozano copied a report in which Valdivia described his experience with the Mapuche lonkos from Paicaví. According to Valdivia, when he met the lonkos, he preached to them what seems to have been a version of Acosta's first three sermons. ${ }^{58}$ After this, and in a calculated display of piety, Valdivia dismissed them and began to read from a breviary. Their curiosity aroused, the lonkos surrounded Valdivia and demanded to know if he was a sorcerer. Valdivia told them he was simply offering his respects to the creator of heaven and earth, thus sparking a conversation in which Valdivia tried to convince the lonkos that some of their customs, such as collective drinking or the practice of polygamy, were sins. They agreed with some of the Jesuit's reasons, but flatly rejected others on the basis that they were practices sanctioned by their traditions. Valdivia asked them to explain him more about these traditions, "wishing to see if there was among them a trace of religion," but the lonkos refused. Next morning, more lonkos arrived to talk to Valdivia. As he began preaching again about the one God creator, one of them, Aivilú, interrupted him by saying that the Mapuche needed to believe in only one god, Pillán, who had created them all and who rewarded the lonkos and the warriors with a place in the sky. This was plain for everyone to see, continued Aivilú, because every sunset Pillán exalted the warriors by displaying in the sky the blood they had shed. Seizing this opportunity, Valdivia asked his audience whether Pillán had a body or whether it was a purely spiritual being. "And here they tried to satisfy my curiosity, answering with a lot of nonsense, to which I smiled, saying that I felt pity for them, for although some of the things they said were right, they were mistaken in a thousand others, due to their lack of books." 59 This remark was intended to bring to the lonkos' mind Valdivia's display the day before of the book (and, by extension, of the literate priest) as the proper mediator between creator and creature. After a debate, in which Valdivia claimed to have shown them how neither Pillán nor the souls of the

\footnotetext{
58 Pedro Lozano, Historia de la Compañía de Jesús de la Provincia del Paraguay (Madrid: Imprenta de la viuda de M. Fernández, 1755), 382. 
warriors could eat or drink in the afterlife for they lacked bodies, he concluded: "And so, the one you call Pillán cannot be what you claim he is, or else he is our God."60 The lonkos admitted that Valdivia was right: "Good is God, and we want to serve Him so He will take us to Heaven. But it is your duty to teach us, for we do not know what is convenient for us." 61

In spite of the triumphalism of Valdivia's report, one must ask: What did the lonkos recognized as the truth? Valdivia had explicitly said that the native divinity Pillán was also the Christian God; and the word he used to express "heaven" was, in all likelihood, huenu, literally, "the place above; the sky." This was the same word Aivilú would have used to refer to the place where Pillán rewarded the souls of the lonkos and the conas, and also the one used by the lonkos in their acceptance of Valdivia's mission. Moreover, right after identifying Pillán with the Christian God, Valdivia had urged the Mapuche to praise God/Pillán for having inspired Philip III to abolish the dreaded personal service and the forced labor in the gold mines, offering a general pardon to all those who had rebelled but now accepted the Spanish rule. Both Valdivia's effort to accommodate Mapuche beliefs to Christian teachings and the lonkos acceptance of his reasoning, then, were politically motivated, and acted in the best interest of both parties. Not unlike the compromises between the Confucian Mandarins and Matteo Ricci, Anvilú and Luis de Valdivia devised a common ground, a compromise between their cultures that enabled both to feel that each had gotten the upper hand.

\section{Conclusion}

Here, we can see the limits of the missionary use of accommodation, or, to put it in another way, some of the reasons why Acosta (or the mendicant friars in seventeenth-century China) had dreaded its use so much. But Valdivia's attitude towards accommodation and Mapuche culture more generally in the second part of his career is also instructive from a methodological point of view. Whereas during his first years in Chile, when he devoted himself to administration and the teaching of theology, Valdivia favored radical forms of acculturation, such as the enslaving of the Mapuche and their forcible removal from their communities, a more sustained and prolonged contact with them and their culture led him to try and accommodate some aspects both of the Christian dogma and of native traditions. To be sure, this was a tactical move,

$\begin{array}{ll}6 \text { o } & \text { Ibid., } 385 \\ 61 & \text { Ibid. }\end{array}$ 
but accommodation is always a tactical move, as Ricci's rejection of the Buddhist image devised by Ruggieri to don the robes of a Chinese scholar makes clear. The different examples and attitudes toward accommodation that I have discussed here allow us to see not just the "rhetorical principle" of accommodation, but also the sometimes contradictory ways in which this principle was translated into action in specific missionary settings.

Seen in this manner, we can begin to understand how and under what conditions the Jesuits were able to translate the rhetorical principle of accommodation into a proselytizing praxis. Two conclusions can be drawn from the previous discussion. The first is that the needs in the missionary field seemed to have always superseded and overruled the theoretical requirements set beforehand. Efforts such as those of José de Acosta in order to stem the use of crosscultural elements and to prefer inculturation over accommodation ultimately resulted in a partial failure precisely because of the missionaries' need to take into account the diverse political and cultural settings in which they had to work. The second conclusion has to do with this diversity of settings. Whereas all the examples discussed here can be firmly placed within the European colonial expansion of the early modern period, not all the missionaries were able to exert the same authority over native peoples. In late sixteenth-century Peru, where coercitive structures had been put in place by the reforms of Viceroy Francisco de Toledo (r. 1568-81), Acosta could simply assume that Christianity would be imposed from the top down. The same was not true for the likes of Ricci or Valdivia, a fact Acosta himself had recognized in De procuranda. There, he distinguished between three kinds of "barbarian" peoples, each of which called for a different missionary strategy. Acosta specifically named the Chinese and the Japanese peoples among those for whom conversion should come about by rational argumentation. ${ }^{62}$ For all other peoples, continued Acosta, some degree of colonial rule and coercion were necessary. But what Acosta increasingly refused to concede was that, for those Jesuits working in missionary settings such as Ming China or early seventeenth-century southern Chile and Paraguay, some negotiation was needed in order to achieve a common ground with their would-be converts if their mission was going to happen at all.

Although accommodation as a rhetorical principle permeated the discourses both of the Acostas and the Riccis of the early modern period, their actual missionary preferences and practices were determined, in a large measure, by the realities they encountered in the field and the specific obstacles they needed to negotiate. In this sense, we would do better in talking of accommodation

62 Acosta, De procuranda Indorum salute, 1:63. 
as a range of practices going from cross-cultural adaptations and negotiations (as in the cases of Ricci and Valdivia) to the rigorist interpretation found in the injunctions against accommodation in Acosta's late writings. For most Jesuit missionaries, accommodation was somewhere in between these two poles. It is in the often complex negotiations between catechist and catechumen where we can see both the benefits and the pitfalls of this strategy, as well as measure the gap between theory and practice; between rhetorical principle and applied rhetoric. 